\title{
The Vietnam Central Coastline and the Emergent Nguyễn State, c. 1500-1700: Port, Coastline, Hinterland Interrelations
}

\author{
Ilicia J. Sprey \\ Ivy Tech, Lafayette
}

\section{Abstract}

This study, building upon earlier works published from 2011 to the present, focuses on sixteenth through eighteenth century Cochinchina's upstream-downstream networked relations and how they contributed to the re-development of the region's economy and consequently its political and social development, with particular emphasis on its coastal ports and related trade under the Nguyễn. These relations revolve around tightly connected interactions among diverse groups including long-term resident diasporic Fujian merchant communities, newly introduced Chan Buddhist monks, maritime-based Chinese pro-Ming piratical syndicates, local Cham raiding cohorts, and the alien Nguyễn clan who in 1600 claimed political authority over the Vietnamese littoral's central coastal region (Trung Bộ) and extended central lands (Miền Trung). The partnerships the Nguyễn established with each of these groups (merchants, monks, pirates, upstream and downstream multiethnic communities) enabled the major ports of Đà Năng, and particularly, of Hội An, to thrive and produce the income needed to support both the Nguyễn bureaucracy and its military conquest of the southern third of the littoral. Over the course of the seventeenth and into the eighteenth centuries, the Nguyễn co-opted the cultural, spiritual, and maritime-based power and influence exercised by each of each these 
groups in an initial effort to fulfill its dynastic ambitions that remained unfulfilled until 1802. This work moves beyond other regional studies by using the approach proposed in Michael Pearson's writings regarding the Indian Ocean ports-of-trade littoral and extending them eastward, to the further edges of the Indian Ocean borderless world, and applying them to the complex interactions of the Vietnamese littoral populationscoastal urban and hinterland - as they contributed to the development of the central Vietnamese littoral's ports-of-trade and of Nguyễn authority and power in this era.

\section{Key words}

Chan Buddhism, Cochinchina, Đai Việt, Đà Năng, Dashan, Fujian, Hội An, Huế, Lê, Nguyễn, Nguyễn Hoàng, Thanh Hóa, Trịnh, Trung Bộ, Vân Đồn, Zheng Zhilong

\section{INTRODUCTION}

The present study is not meant to be inclusive of all aspects of the economic and political development of Nguyễn authority in the region known variously as Cochinchina or Đàng Trong. Its purpose is to provide an introduction or overview to the sixteenth through eighteenth century development of local agency and the leadership that the Nguyễn Lords exercised in coastal, regional, and transregional maritime-based trade. Their approach in supporting maritime-based commerical trade and effective authority over their ports-of-trade and related upstream and hinterland networks was more deliberate and intense than that offered by the rulers of the northern kingdom of Đai Việt and other regional powers. As such there is the opportunity to apply the approach and ideas regarding the development of maritime authority in this same period in the Indian Ocean world as presented by Michael Pearson in his multiple works over the last several decades to a neighboring region, the Vietnamese littoral and the South China Sea in an effort to better contextualize the role that Đàng Trong played in this era's maritime-based commercial exchanges and to better understand how unique the effective exercise of authority by the Nguyen over its own maritime trade actually was. 
After the Ming China military invasion of 1406-1407 and the subsequent period of Chinese occupation and political domination that lasted until 1426 Đai Việt's Lê emperors reestablished Vietnamese sovereignty in the northern third of the littoral. They followed achievement with a military expansion southward into the littoral's central region that was aimed at defeating regional rivals including the Champ, Laotians, and Khmers. ${ }^{1}$ Victory against the Cham realm, the closest and most significant political, military and economic rival came in 1471. The Champa kingdom had controlled the Vietnam littoral's southern and central coastal regions and their linked upstreams and hinterland populations had provided raw and finished goods that had made their ports an important part of both coastal and regional maritime trade from the seventh through the twelfth century at which point its fortunes in all senses had begun to decline. This 1471 victory allowed the northern Viet relam over the next hundred years to expand into the former Cham lands and to establish little by little both its military and administrative authority in the lands immediately south of Đai Việt. Understandibly, the north's victory and seizure of lands that had once contributed to the Cham polities agricultural and commercial wealth negatively impacted the level of international trading opportunities to be found in these ports from the late fifteenth century onward. Thus, the economic vitality of the former Cham coastline port communities and its upstream suppliers of raw materials and the communities living around the ports who supplied labor and provisioned ships was devasted by the loss of both political independence and commercially generated income. ${ }^{2}$ The situation was further exacerbated by actions taken by the Đai Việt administration post-1471 both to further weaken economically the remnant of the Cham kingdom that continued on as essentially a tribute

\footnotetext{
1 John K. Whitmore, "The thirteenth province: Internal administration and external expansion in fifteenth-century Dai Viet," Asian Expansions: The historical experience of polity expansion in Asia. Edited by Geoff Wade. (London: Routledge, 2015), 144-66.
}

2 John K. Whitmore, "The Rise of the Coast: Trade, State and Culture in Early Đại Việt", Journal of Southeast Asian Studies 37.1 (2006): 103-22. 
state and to increase the north's own commerically generated trade revenue.

Arguably the most significant action taken to weakend the southern ports and to strength those of Đai Việt was that the Lê administration forcibly removed Cham ceramic artisans from their homelands and moved them closer to the northern ports so that their wares would be available only there. This action had long term consequences for the Cham people as it crippled the many communities that had been dedicated to ceramic production. One consequence of this relocation was that regional and international maritime-based trading vessels that once had stopped in Cham ports to purchase these much sought after goods had to travel further north along the coast to the Đai Việt controlled coastline ports, most notably Vân Đồn among others in the Red River delta, as well as ports in Nghệ Tĩnh province. ${ }^{3}$ While dominated by Confucianist attitudes that were largely negative towards trade, in the period from the eleventh through fifteenth centuries the Lê treasury received considerable income from its ports and its maritime-based trading partnership with China and as a intermediary between hinterland producers of raw materials and Southeast Asian merchants. This new revenue stream and the gain of new agricultural lands and associated human and natural resources, all served to strengthened the regional position of the northern kingdom. The revenue provided funds for further military expansion to the south and the conducting of warfare against the remaining regional rival polities. The lands brought under northern authority came to be increasingly populated by Vietnamese seeking a fresh start and the opportunity to move away from lands that had experienced ongoing cycles of drought, famine, and warfare. This "push to the south" or Nam Tiến was a migration of various groups, including peasants,

\footnotetext{
3 John Whitmore, "Vân Đôn, the "Mạc Gap," and the end of the Jiaozhi Ocean System: Trade and State in Đại Việt, Circa 1450-1550', in Nola Cooke, Li Tana, and James A. Anderson eds., The Tongking Gulf Through History, (Philadelphia: University of Pennsylvania Press, 2011), 101-16. See also, Momoki Shiro, "Dai Viet and the South China Sea Trade from the $10^{\text {th }}$ to the $15^{\text {th }}$ Century," Crossroads, 12 (1): 1-34, and Nguyen Van Kim, "Van Don: An international sea port of Dai Viet," in Early Modern Southeast Asia, 1350-1800. Edited by Ooi Keat Gin and Hoang Anh Tuan. (London: Routledge, 2016).122-35.
} 
who particularly in the period from the early fifteenth century through the mid-eighteenth century moved away from the provinces that had formed the traditional basis of the northern kingdom. 4

The sixteenth century witnessed not just this pattern of population relocation and related loss of agricultural revenue for the northern kingdom, but also political turmoil and civil war. In 1527 the Lê monarches were overthrown when the rival Mạc clan usurped the throne. In 1533 the Lê dynasty was restored to power by the Trinh clan whose head held the actual reigns of government with the Lê being emperors in name only. With the Lê monarchs under the virtual control of their Trịnh relatives, the Trịnh and Mạc continued their struggle for political control. Nguyễn Kim (1476-1545), the head of the Nguyễn clan, whose family had long served the Lê rulers sided with the Trịnh. He was assassinated in 1545 by a Mac supporter and his older son was shortly thereafter poisoned. Wanting to remove himself from the political violence and not wanting to become the object of an assassination attempt, Nguyễn Hoàng (1525-1613) asked his brother-in-law Trịnh Kiểm (1503-1570), the founder of the Trịnh Lords and head of the loyalist army, to appoint him to a military posting in the newly expanding southern border region. ${ }^{5}$ His request was granted and beginning in1558 he provided outstanding and effective loyal service on the frontier asserting Đai Việt's military, economic, and administrative control over these southern lands. As military and administrative commander he continued the southern expansion until the ascension of Lê Kính Tông (1600-1619) as emperor. ${ }^{6}$ While

\footnotetext{
4 The evidence fo this push to the south is found going back to at least the eleventh century and earlier periods of Chinese invasion and domination. For more on the later period of this southward movement see Yumio Sakurai, "Peasant Drain and Abandoned Villages in the Red River Delta between 1750 and 1850", in The Last Stand of Asian Autonomies: Responses to Modernity in the Diverse States of Southeast Asia and Korea, 1750-1900. Edited by Anthony Reid. (New York: St. Martin's Press, 1997), 133-52.
}

5 Keith W. Taylor, "Nguyen Hoang and the beginning of Viet Nam's southward expansion," in Southeast Asia in the early modern era. Edited by Anthony Reid. (Ithaca: Cornell University Press, 1993), 42-65.

6 These Cham regions immediately south of Đại Việt were conquered in 1470-71 under the personal military leadership of then ruler Lê Thánh Tông (r.1460-1497). 
the reasons for initiating a break at that moment are not perfectly understood, what is known is that Nguyễn Hoàng refused to obey any further the Trinh controlled court's orders while declaring his and his family's enduring loyalty to the Lê monarchs, and claiming lordship over the lands he had previously overseen for the northern kingdom. ${ }^{7}$ The territorial and economic base for this calculated move by the Nguyễn was not in the northern province of Thanh Hóa from which they originated, but the former Cham central lands of Trung Bộ ("central coast") and Miền Trung Việt ("central Vietnam"), known collectively as Đàng Trong ("inner region" by the Cham versus Đàng Ngoài ("outer region") that was used by the Cham to describe the northern kingdom and people of Đại Việt, who were the regional outsiders.

The region of Đàng Trong was strategically important economically, militarily, and administratively for the Nguyễn clan's future. Nguyễn Hoàng had conquered and effectively administered the region over the better part of four decades, enforcing laws that were fairly applied to both the Viet and other populations present in these lands, respecting local religious deities and cultural practices without attempts to "civilize" them by "Vietnamization" which the northern kingdom undertook in relation to those they directly conquered. The region's population had generally been pacified by and under him, and had come to accept him as a reasonable and fair regional administrator whose presence generally benefitted them and their families, their revitalizing businesses and agricultural efforts. Resistance to his exercise of authority grew increasingly sporadic over time. His military interest lay south of them and so in general the local populations benefitted from the peace he ensured, his lack of interest in challenging or changing their local religious traditions, and his deliberate efforts to promote and rebuild the economy prosperity of the region from the century or so of economic depression it experienced since 1471. On this last point, it should be noted that both before and after he lay claim to the lordship of this region he worked with local merchant groups helped to create attractive marketplaces

7 Taylor, "Nguyen Hoang and the beginning of Viet Nam's southward expansion, op.cit. 
for the local population and for those who came in increasing numbers by land and water to sell and buy goods and foodstuffs. He ordered the rebuilding of ports to encourage regional (coastal and riverine) and trans-regional maritimebased trade, and allowed these commercial centers to be run by the merchants and overseen by port administrators so that they could operate as efficiently as possible without being under the shadow of overt political or military presence.

Under his command, his administration actively worked to restore and expand the coastal ports that had been the economic engine of the Champa kingdom in its hay day. To achieve this, he worked to re-establish the mutually beneficial system whereby the hinterland and mountain-dwelling population provided to the coastal ports via a chain of exchange much of the most of the more exotic goods - fragrant wood (aloeswood, eagleswood, and sandalwood which was in high demand by the Indian market for use in religious ceremonies), deerskins, etc. - desired by maritime traders for regional markets and those further afield. Coastal villages and those closer to the ports supplied equally valuable finished goods, including silk. ${ }^{8}$ By 1600 Nguyễn Hoàng had followed in the policies of early Cham rulers by focusing on establishing a regional economy that was supported as much by coastalbased commercial trade as by agriculture, by creating favorable conditions for the re-establishment of coastal, regional, and trans-regional maritime commercial trade patterns that focused on the primary, secondary, and tertiary central and southern ports. He ordered ports and harbors that had suffered economic decline and physical deterioration in previous decades and centuries to be reestablished and or restored to working conditions (i.e. de-silted, widened, etc.) while making the port as attractive to monsoon-driven trading vessels and their merchants-owners and captains by building or encouraging to be built warehouses, temporary, semipermanent, and permanent communities of merchants and 
those who supported their trading interests, and structures to meet their religious and cultural needs. Within a decade of claiming lordship over this territory, the Nguyễn Lord had created a seasonaly four-month annual fair to attract a greater portion of the coastal and regional trade. The monsoon season for this area was primarily from August to November, and most regional trading was done between April and July. There was thus a seasonal window of opportunity when shipping laid over at Hội An, the Nguyễn's primary port for most of the seventeenth century. Not only were the merchants gathered there able to sell pepper and locally produced silk, ivory, and fragrant woods, but they could trade for highly desireable goods from the Indian Ocean world, including Gujarati cloth. These would be the same approach and practices that formed the foundation for the early rule of Nguyễn Hoàng and his successors who collectively are referred to as the Nguyễn Lords.

As noted above, the available fertile land in this central and southern portion of the littoral was more than the sparse Cham and other resident ethnic populations could work and the Nguyễn Lords were welcoming to the Viet population looking to leave warfare, drought, and famine behind them and start over as both agriculturalists, merchants, and as much-needed members of an initially small bureaucracy. The Nguyễn had long been practitioners of Mahayana Buddhism and as a result as they established their own administrative bureaucracy in Đàng Trong. For most of the seventeenth century Nguyễn administration was noted as being an available path for men of talent regardless of ethnic identity - Chinese, Malay, Arab, Viet, Japanese - as these men brought knowledge of the diverse markets in the larger South China Sea, Straits of Melaka, the Indian Ocean, and the Sea of Japan - as well as language skills and awareness of diverse cultural practices that allowed the Nguyễn-controlled ports to attract more foreign merchants over time. $^{9}$

9 The downside of this approach was that the Nguyễn was far less effective in revenue assessment and collection and often declined or just failed to collect taxes owed to it in exchange for military service by male householders or to avoid creating regional social disruptions. While the economy was booming and the ports were attracting large portions of 


\section{The ports of Đà Năng and Hội An}

Having declared their de facto independence of the northern kingdom, the Nguyễn established their permanent capital at Đinh Cat (modern-day Huế) as it was protected to the north and the west by rugged mountains that stretched across the narrow littoral to the coast. Thus, the nearby south-central ports of Đà Năng ${ }^{10}$ and Hội An (in modern day Quảng Nam province) were deliberately left free of the overt and omnipresent political influence of an administrative capital and military garrison in order to encourage the economic growth and financial profits, most of which derived from the commercial activities of numerous international maritime diaspora who settled in these ports. Đà Năng, located on the Hàn River estuary, and Hội An, located approximately 20 miles south of Đà Năng on the Thu Bồn River estuary, enjoyed great economic prosperity due to the depth of their respective harbors (particularly in the case of Đà Năng in the eighteenth century on as deeper drafting European vessels arrived in greater numbers) and the protection against storms and attacks that the locations offered (particularly true of Hội An being upstream and less exposed). Hội An was also of sufficient size so that visitors in the seventeenth century would marvel at the forest of masts as ships were unloaded and loaded at the multiple quays with very little delay. Working in tandem with the dynamic governmentdriven the commercial efforts the diverse multi-ethnic

regional maritime-based trade, the revenue collected via commerce was sufficient to support both the bureaucracy and the military expansion. However, as regional trade decreased in the late seventeenth century and the early eighteenth century, inflation set in, and lack of successful economic reforms, led the Nguyễn government to adopt Confucian-oriented practices and a determined effort to collect previously neglected revenue streeams at the very time the economy and individuals could not afford or would not accept paying more in support of what was increasingly seen as a foreign and oppressive governemnt. This led in large part to the Tay Son rebellion agains the Nguyễn later in the eighteenth century.

10 Đà Nẵng was also known as Của Hàn and by the French later on as Tourane. In 1997 the city was separated from Quảng Nam- Đà Nẵng Province and placed under the authority of the central government. Hội An, also known early on as Faifo by Europeans, may have been the main port for the Cham religious center of Mỹ Sơn and the former Cham capital of Trà Kiệu, located upstream. Many of these secondary ports have expanded into the modern port-cities of Phan Rang and Nha Trang. 
merchants and suppliers to the ports drew upon the rich natural resources particularly of the region's extended upstream and hinterland populations and forests to meet expanding regional marketplace demands. (See Map 1) Villages around these ports often became dedicated to supplying specific products such as birds nests for medicinal use, wood carving, and silk production. Đà Năng and Hội An were considered the premier ports of the central littoral in this era of transition but the secondary and teriary ports of Đàng Trong also had wellestablished if smaller upstream networks that supplied the downstream littoral with materials often more aimed at local consumption, but that sometimes also found their way into the larger coastal markets.

While particularly true of Hội An many of these other ports enjoyed permanent and semi-permant resident maritime diaspora that included South Asians, Thai, Malay, and Indonesian, Chinese, Japanese, Indonesian, Middle Eastern. In the sixteenth century, the earliest wave of European merchants and seamen arrived using both the northern kingdom and the Đàng Trong ports as an entry point into first Chinese and Japanese trade. Ships paid fees to the port authorities based on the cargos they carried and how far they had travelled since their last port of call, etc. and so the increased number of ships generated a steady stream of revenue for the rulers. Over time the focus expanded to include participation in the trade originating from or passing through the Vietnamese littoral from the Ayutthaya and Khmer kingdoms through ports such as Hội An. Like the Cham rulers before them over the course of the seventeenth century in this period of economic boom, the Nguyễn Lords found themselves increasingly paritcipating in regional and international trade routes that connected them not only to the commercial activites of the nearby China Sea to the north, the Straits of Melaka and Java Sea to the south, and the Sulu Sea region of the Philippines to the east and the Indian Ocean to the far west. ${ }^{11}$

11 The Portuguese explorer, Antonio de Faria (d.1548), arrived in Đà Nẵng in 1535 and is thought to be the first European to comment on Hội An. See Brian A. Zottoli, 
Calculated economic support for increasing participation in coastal and regional trade in relation to Hội An and its neighboring ports meant Nguyễn Lords initially focused in establishing partnerships with the resident Fujianese Chinese maritime diaspora already present in the region for approximately a century. ${ }^{12}$ They worked together on the rehabilitation and expansion of the region's productive primary and secondary ports, and with the support of this diaspora, the Nguyễn implemented port- and market-related legal codes and policies that assured secure and equal access for all to the markets (i.e. no preferential treatment for Vietnamese, no detremental treatment of non-Vietamese). As noted above this approach had been used by Nguyễn Hoàng in pacifying and rebuilding the territories he oversaw as military and administrative administrator. This approach and these laws were unique for the immediate and larger regions both as they applied equally to all newly established permanent and semipermanent multi-ethic and multi-cultural trading community enclaves. Hội An quickly surpassed the importance of its neighboring port at Đà Năng to become the most prominent of the regional international ports-of-trade in the seventeenth through middle eighteenth centuries, at which point the decrease in trade and the associated drop in regional economic prosperity, inflation due to lake of local minting of coins, political unrest and a shift in policies, all helped to mark the decline of these ports. Hội An also suffered from increased silting that was not addressed in a timely manner. After the unification of Vietnam in 1802 Đà Năng again took on a lead role in trade as its deeper harbors were found to better suit the expanding number of European ships present in the region. In its hay day under the Nguyễn, Hội An was a point of access to lucrative regional coastline and upstream products many of which originated in the mountains of the littoral. Among these items were valuable fragrant woods - notably sandalwood, aloewood

98, and Spencer Tucker, Vietnam, (Lexington, Kentucky: University Press of Kentucky, 1999), 22.

12 Chinese presence at Hội An can be placed to at least 1444 when a Fujian-based monk built the Buddhist temple of Chua Chuc Thanh there. 
and eaglewood to be refined into incense for use in various temple and religious rituals, timber for building and ship construction, agricultural and animal products such as deerskin and sharkfin and mulberries for silkworm cultivation, and silk and other fabrics of various qualities.

Following their conquest of the critical Melaka Straits of Melaka emporium in 1511, Portuguese merchants were the first Europeans to negotiate favourable alien diaspora resident community status. They established a trade "factory" at Hội An as one among other diaspora community residential enclaves including ones previously put in place by the Chinese diaspora merchant community and one by the permantly resident Japanese merchants and their families. While the Portuguese also had a presence in Đai Việt ports to the north, that region's products were of marginal interest to the international traders, and the Hanoi-based Lê emperors and subsequently the Trịnh showed little interest in enhancing their downstream's commercial role in wider South China Sea and Indian Ocean trade in the sixteenth and seventeenth centuries. They preferred, instead, to retain their focus on Đai Việt's long established trading connections to south China's ports-oftrade. ${ }^{13}$ When the Portuguese contracted exclusive port-oftrade space at Macao in 1557 and its Jesuit representatives negotiated trading rights at the emerging Japanese emporium at Nagasaki in 1569, Hội An became the critical Portuguese sixteenth through the end of the seventeenth-century intermediary port as the preferred stopping nad trading point between Melaka and Ming China and Tokugawa Japan.

\footnotetext{
13 Đại Việt's ports-of-trade were tied almost exclusively to mainland China's producers and markets due to proximity and the political and economic dominance China played in the region's existence. Lê and Trịnh disdain for trade beyong that with China is evidenced by a 1624 letter written by Trịnh Tráng (r.1623-54) and addressed to the Tokugawa Shōgun, which reads in part: 'we are interested in getting on good terms with your government rather than [with] those small traders.' This was followed by a 1627 letter in which Trịnh Tráng spoke in condescending terms about foreign trade, but grudgingly sent as 'a grant' ten bolts of silk. (Kawamoto Kuniye, 'The international outlook of the Quang Nam', in Ancient Town of Hoi An: International Symposium held in Danang on 23-23 March 1990. The National Committee for the International Symposium on the Ancient town of Hoi An. Hanoi: Foreign Languages Publishing House, 1991), 111-12.)
} 
By stabilizing the Hội An coastline and its adjacent upstream-based resources including forest products the emerging Nguyễn monarchy gained a vital source of guaranteed revenues to support their ongoing central Vietnam borderlands wars with the Trịnh (1627 to 1673 settlement), and also to successfully conquer via land and sea the southern third of the downstream littoral from the remnants of the remaining and considerably smaller Champa kingdom. To secure their military and political position against that of the northern powers of the Trịnh led court, the Nguyễn's goal was to expand their economic resources by gaining control of the prosperous Mekong River Delta and its related upstream sources of raw materials and abundant agricultural production (particularly of rice), its human/labor resources, and the access it provided to Khmer-held lands to the west. ${ }^{14}$ In 1698 Nguyễn Phúc Chu, ruler of Cochinchina, (r.1691-1725) sent an expedition south that brought the Mekong Delta under Nguyễn control, establishing the garrison at Gia Định (Saigon), and allowing the Nguyễn to further engage for territorial and economic resources with the Khmer kingdom and Thai.

In their seventeenth-century expansion into the central and southern regions of the littoral, the Nguyễn Lords used innovative partnerships with prominent coastline-based resident Cham, expatriate Việt and Cham populations, and other minority and multi-ethnic groups. These diverse groups in one form or another had come to call the region "home," as had to a certain extent the diasporic merchant communities, primarily from Fujian province, who would come to act as patrons of the "missionary" Chan Buddhist monks in their efforts to penetrate the central and southern region's upstreams. These upstream and hinterland regions were where the local peoples provided the raw materials and other locally produced commodities that supplied the downstream trade that ultimately fed into and centered on the coastal ports of the littoral, most especially Hội An and Đà Nẵng. The Nguyễn further enhanced the

14 Charles Wheeler, “A Maritime Logic to Vietnamese History: Littoral Society in Hội An's Trading World, c.1550-1830," paper presented at Seascapes, Littoral Cultures, and TransOceanic Exchanges, Library of Congress, Washington, D.C., 12-15 February 2003. 
attractiveness of their ports by striking deals that led to a considerable decrease of regionaal competition from the Thai and Khmer ports and major regional market centers. The Nguyễn were able to effectively channel many of the goods provided by Thai and Khmer upstream urban centers to their own coastal ports thus making them that more accessible to those plying those trade routes focusing on China and Japan. They did this not by warfare, which would have been costly, but by offering lucrative trading partnerships to the merchants and the administrators overseeing the Thai and Khmer ports-oftrade and their related markets. In exchange, these groups found it advantageous to channel to Hội An and Đà Năng many of their goods that were in high demand by those plying the Japanese and Chinese trade routes. Such upstreamdownstream produced goods and raw materials that were in high demand. This variety of networked relationships increasingly centering on Hội An formed the two "wheels" of commerce that together propelled the Nguyễn Lords to economic and political prominence over the central and southern Vietnamese littoral with varying levels of control and/or influence over the regional upstreams from the late sixteenth through the early-eighteenth centuries. ${ }^{15}$

15 For the most comprehensive study of Nguyễn power in its pre-dynastic unification of the littoral, see Li, Tana, Nguyễn Cochchina: Southern Vietnam in the Seventeenth and Eighteenth Centuries (Cornel: SEAP, 1998). 


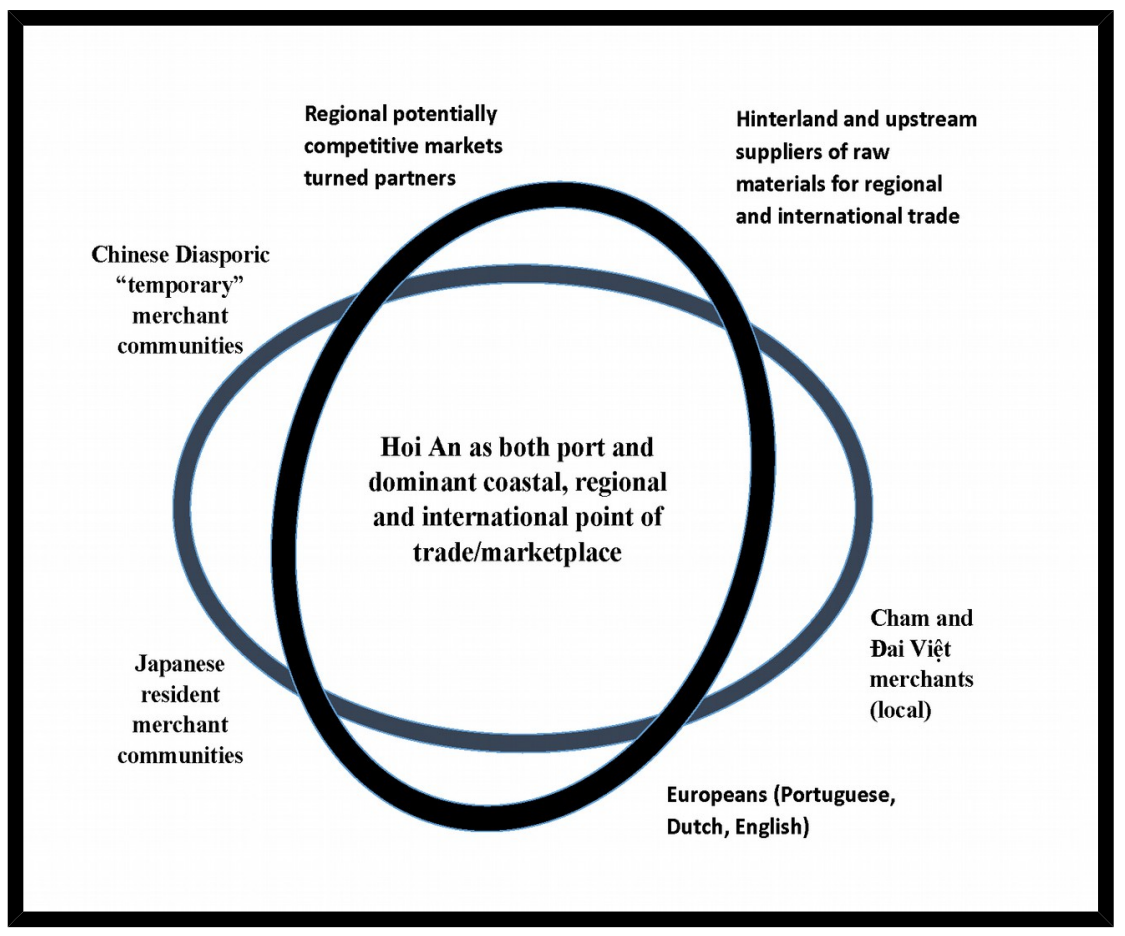

Figure 1: Diagram of those factors and partners that made Hội An the economically and commercially dominant Việt port-oftrade in the late sixteenth through early eighteenth centuries.

III. Piracy, Entrepreneurs, and Partnerships on the Vietnam Coastline

Nguyễn Hoàng, knew that it was in the littoral's ports that were now under his control that this family's future lay. The Nguyễn were outsiders, with only a small military force loyal to them and no local cultural or familial ties, who needed to maximize their economic resources in order to survive the political gambit he had undertaken in 1600 when he broke from the authority of Đai Việt and thus committed an act of treason and an initial step in what would be seen only in hindsight as state-building. His economic success would be built upon the region's earlier economic success under the Cham rulers and that had been firmly founded in the numerous well-proportioned and wellpositioned harbors and ports of Cochinchina or as known then as Trung Bộ. From the start, Nguyễn Hoang worked to gain preference for his port related markets from all (Đai Việt excepted) potential trading partners and he set his eye most particularly on gaining a signficant portion of the reliably profitable trade bound up with the Japanese upperclass 
demand for luxury goods. The level of his and his successors achievement of this goal of gaining preferred status for coastal ports in Nguyễn held lands is found in the number of Shuinsen or "Vermillion" seal ships officially sent by the Tokugawa governemnt to trade abroad. In the period between 1604 and 1635 (the latter being the year the Japanese banned all trade abroad by its own merchants), the ports of Cochinchina received 70 Shuinsen ships, which significantly outdistanced the other regional ports-of-trade doing business with Japan: Siam 56; Luzon 53; Cambodia 44; Tongking 36; Annam 14 and Champa 5 (e.g., Mekong Delta regional ports not yet under Nguyễn direct control or indirect influence in this period). Approaching the data in a slightly different way the Vietnamese historian Vu Minh Giang calculated that between 1604 and 1634, 331 of 534 Shuinsen ships (93.5 per cent) went to Southeast Asian ports, 130 of those went to Vietnamese ports, and 86 of those went to Hội An, which would mean that 26 per cent of all ships sent to Southeast Asia went to that port. ${ }^{16}$ This grew slighly more when Champa become a vassal state under the Nguyễn, a position that was solidified with Nguyễn Phúc Nguyên's (r.1613-1635) marriage of his third daughter Lady Nguyễn Ngoc Khoa to the Cham King Po Rome (r.16271651). ${ }^{17}$ In addition to the open, fair, and competitive marketplaces Nguyễn Hoang established in his ports-of-trade that were intended to encourage ship captains and merchants to put in at Hội An, Đà Năng and other secondary and tertiary ports of his lands, what also mattered as much to the Nguyễn was what merchants founds when they came ashore. An early eighteenth-century Cantonese trader provided his perspective of the differences between trading in Trung Bộ's ports-of-trade

16 Li Tana, Nguyễn Cochinchina, Table 1, 62; Vũ Minh Giang 'The Japanese presence in Hội An,' in Ancient Town of Hội An, 136.

17 While there are no contemporary documents that mention this Viet-Cham marriage, a recently produced geneology of the Nguyen's does. (Vinh Cao, et.al, eds. Nguyễn Phước Tộc Thế Phả (Geneaology of the Nguyen Phuc Clan) (Huế: Thuận Hóa, 1995), 126 as cited by Danny Wong Tze Ken, "Vietnam-Champa Relations during the Seventeenth and Eighteenth Centuries" in The Cham of Vietnam: History, Society and Art. Tran Ky Phuong and Bruce M. Lockhart, eds. (Singapore: NUS Press, 2011), 246 and 260. n.22. Nguyễn Phúc Nguyên also married another daughter, Nguyễn Thị Ngọc to the Khmer ruler, Chey Chetta II (r. 16181628). 
as its markets compared to those of its contemporary Tongking rivals in terms of what was available for purchase in the marketplace, and whether it was worth the time, cost, and potential travel to travel there from Guangzhou:

It takes four days and nights and one geng [2.4 hours] to Sơn Nam [Tongking's primary port-of-trade at that time], but the goods that can be carried back are nothing but rice and from Thuận Hóa only pepper. Whereas the goods that can be brought from Quảng Nam [the province in which Hội An is located] are so abundant that it seems nothing cannot be obtained from there; it is superior to all other ports of Southeast Asia. ${ }^{18}$

This abundance of desirable goods for purchase in the ports of Hội An and Đà Năng were built in large part both on the earlier mentioned establishment of beneficial trading arrangements with the Thai and Khmer markets that marked the early decades of Nguyễn rule and the encouragement of local production of raw and finished goods, and the Nguyễn support of strengthening and increasing upstream provisioning of downstream commerical needs. Wanting to insure that the competitve edge in regional trade they were deliberately carving out for their ports was supported in as many ways as possible, the Nguyễn Lords also followed in the approach of of pre-1500 Champa upstream-downstream-networked polities, and chose to unofficially partner with local piratical groups, largely coastal and lower riverine fishermen, many of whom were ethnically Cham. The Nguyễn thus tolerated well-directed maritime raiding (piracy) and illegal smuggling activities when and as they were beneficial to their state-building interests and supported the development of politically stable and revenueproductive commodity flows. Freed of the constraints of Confucian obligations to one's lord by his rebellious act of seizing Cochinchina for him and his family to rule over, ${ }^{19}$ Nguyễn Hoàng thus moved beyond the initial networked

18 Chen, a Chinese merchant quoted in Lê Quý Đôn, Phu bien tap luc, vol. 4, 34b cited in Li Tana, Nguyễn Cochinchina, 69-70.

19 Taylor, 'Nguyễn Hoàng and the Beginning of Vietnam’s Southward Expansion', op.cit. 
relationships with the preexisting communities of multi-ethnic maritime raiders on the Central Region coastline, tolerating small acts of piracy by local coastal populations and also with similar but more sophisticated groups, specifically diasporic Chinese pirate-diasporic communities. These seaborne entrepreneurs, if one is being generous, whose actions were "regretably beyond the control of the ruling lord to control" were desireable "partners" for the Nguyễn helping to decrease the level of participation in trade of the remaining rival Cham ports to the south, as well as northern Vietnamese and Chinese ports-of-trade, while increasing the promince and security from piracy of his own coastal ports with the intent of their becoming the preferred regional intermediary ports-of-trade in the South China Sea maritime passage between Melaka, China, and Japan.

The regional and international impact of such politysupported piratical activity could be considerable both in direct consequences by encouraging avoidance of southern Cham and northern Đai Việt coastal or upstream ports in favour of the more diversely supplied Nguyễn ports of Hội An and Đà Năng on the central coastline. Critical South China Sea shipping lanes have until modern times designated passages very close to the central region's coastline as large vessels, whether on their way to or from China and/or Japan, Taiwan, and the northern ports of Vietnam, had to pass through treacherous open waters. Strong winds and unpredictable currents combined with the '10,000' scattered shoals of the mid-south China Sea Paracels and Spratleys Islands, forced larger vessels to hug the Vietnamese coastline. This coastline passageway presented opportunities for their stopovers in the central region's ports to conduct trade, but also made these vessels and their cargos targets for pirates, local, Cham, or Chinese. Initial research demonstrates that local, Trung Bộbased Cham fishermen/sailors could make a better living or supplement their income by acts of piracy as independent agents, or 'sub-contracted' seamen employed by regional nongovernmental authorities either by attacking shipping that passed along Vietnam's coastline, or by offering their protection if this shipping were to put into a local harbour to transact trade 
(thus becoming subject to a variety of local portage fees). It appears that with a wink and nod Nguyễn leaders then allowed the selling (publicly or in a black market setting often upstream) of seized goods or those "salvaged" from ships the raiders had forced to shipwreck. ${ }^{20}$

From 1600 Nguyễn Hoang was constantly in need of additional income to finance his military ventures against Đai Việt, and this income could only be port-generated, as the Nguyễn's non-Confucian-based administration in its first century of existence was highly generous in waiving taxes on his diverse population. ${ }^{21}$ But he also found ways to coincidentally diminish the economic resources of Đai Việt. By unofficially partnering with maritime diaspora pirate bands and later more formalized piratical confederacies based in the central Vietnam coastline Chinese diaspora communities, he and his successors were able to increase its regional ports' percentage of direct and indirect trade with China and Japan. Charles Wheeler describes the Nguyễn policy as one of "unofficial toleration...taking advantage of a legally ambiguous understanding of the conduct of sea trade." ${ }^{22}$ Many of the coastline small raider communities merged into "armed

20 For more on these piratical activities see Wheeler, Charles. "Re-Thinking the Sea in Vietnamese History: Littoral Society in the Integration of Thuận-Quảng, SeventeenthEighteenth Centuries." Journal of Southeast Asian Studies 37.1 (2006): 123-53. For recent work done on 'political pirates' in the Tonkin Gulf, see Niu Junkai and Li Qingzin, 'Chinese 'Political Pirates' in the Seventeenth-Century Gulf of Tongking', in Cooke, Li, and Anderson, eds., The Tongking Gulf Through History, 133-42. See Ilicia J. Sprey, "Gunpowder, Pirates, Monks, and Books: Maritime Trade on the Vietnam Coastline, c.1400-1800", in Vanguards of Globalization: Port-Cities from the Classical to the Modern. Edited by Rila Mukherjee. (Delhi: Primus, 2014), 281-320.

21 Efforts by the Nguyễn beginning in the 1720s and 1730s to be more effective tax collectors and to collect taxes they had previously neglected or waived the collecting of led to increasing local resentment of their presence and contributed in large part to both population relocation to the fringes of Nguyễn controlled lands, or beyond their borders, and in time to the Tây Son Rebellion (1771-1802). See Ilicia J. Sprey, "The Far Side of the Indian Ocean: Nguyễn Cochinchina and the Exercise of Local Agency in Encountering the 'Other' in the Seventeenth-Eighteenth Centuries", in Rethinking Connectivity: Region, Place and Space in Asia (Primus: Delhi, 2016), and Li Tana, Nguyến Cochinchina, pp.48-58.

22 Charles Wheeler, 'Maritime Subversions and Socio-Political Formations in Vietnamese History: A Look from the Marginal Center (Miền Trung)", in New Perspectives on the History and Historiography of Southeast Asia: Continuing Explorations. Edited by Michael Aung-Thwin and Kenneth Hall. (Routledge: London, 2011), 148. 
shipping syndicates" to attack shipping from both the rival Đai Việt North led at various times by the Mạc or Trịnh/Lê courts and from the South/ "Qing-loyalist" Chinese diaspora centers that were then emerging in the Mekong delta region. Local Nguyễn officials were charged with and were quite able to manage the protection of friendly shipping (incoming and outgoing) by legitimate merchants (i.e. defined by then unofficially as those using the Nguyễn ports) in the coastal shipping lanes and in port. Technically this piracy would have cost the Nguyễn administration port-generated income, but if or when "friendly" vessels were attacked the Nguyễn port administrators quickly found and severely punished the offenders. Local raiders rapidly learned which ships were politically viable objects of their attention and which to give a wide berth. As those ships attacked by pirates were generally those not intending to come into Hội An or neighboring central coastline ports there was minimal to no economic loss to the Nguyễn. In fact, there was an appreciable gain to them in the long term as those sailing these waters quickly found it either beneficial to put into the Nguyễn regional ports or accept Nguyễn maritime protection as they passed through nearby shipping lanes. Each way generated income to the Nguyễn Lords. Additional benefit to the Nguyễn came in that the multiethnic downstream maritime diasporas' sale of the stolen goods at well under current market prices challenged the commercial dominance of competing legitimate merchants, notably the multiple state-sanctioned or approved Chinese merchant communities based out of the northern Vietnam coastline's official ports-of-trade, such as Vân Đồn, on or near the Red River Delta, who regularly traded with Japan. Hurting Đai Việt's economy was beneficial to the Nguyễn and harming Qingsuppported trade kept the alliance between the Nguyễn and the diasporic Chinese pirate enclaves strong and in place.

In the early seventeenth century the Nguyễn partnerships with the maritime raiders intensified when the reigning Nguyễn Lord, Nguyễn Phúc Tần (r.1648-1687) contracted with the Chinese smuggler-warlord Zheng confederacy, that oversaw an extensive network of intertwined legal, quasi-legal, and quite illegal shipping ventures that allowed him to dominate the 
profitable international trade that transited through the Taiwan Straits. ${ }^{23}$ This passageway was critical to Fujianese merchants' commercial interests, and was also strategically important to the Ming state. The Zheng previously had held a networked relationship with the Ming, to whom he had pledged political and economic loyalty in return for their promise of market access to south China's ports. However, with the 1644 Ming Dynasty's collapse, the Zheng confederacy and their multiethnic maritime allies formed a post-dynastic "Ming-loyalists" network and pledged maritime-based resistance to the newly empowered Qing. As the Qing were able in the 1670s and 1680s to assert their interests in the East Asian littoral, two fleets from the alienated Zheng coalition chose to leave their bases in Taiwan to relocate in an alternative coastline conducive both to trade and to harass Qing maritime interests. ${ }^{24}$ Nguyễn Phúc Tần (r.1648-1687) seized the initiative and offered them a place in his expanding South China Sea networked ports alliance. Subsequently the Zheng's diaspora network used its resources - legal and not so legal - to reinforce expansionist Nguyễn lordship in the southern regions and attack Qing-supported and supportive merchant vessels while defending Nguyễn central coastline-based shipping. The "Ming-loyalists" network sold the goods they seized in Nguyễn markets where the State collected its profitable share in taxes and, most importantly, helped the Nguyễn ports-of-trade to contend in the seventeenth-century competitive high incomegenerating multi-centered trade with Tokugawa Japan, Taiwan, and south China.

The Zheng maritime network also contributed to the successful establishment of Nguyễn authority over the Mekong

23 Patrizia Carioti, "The Zheng's Maritime Power in the International Context of the

Seventeenth Century Far Eastern Seas: The Rise of a 'Centralized Piratical Organization' and Its Gradual Development into an Informal State," Ming Qing Yanjiu (Napoli), 5 (1996), 2967, and Cheng K'och'eng, "Cheng, Ch'eng-king's Maritime Expansion and Early Ch'ing Coastal Prohibitions," in Development and Decline of Fukien Province in the $17^{\text {th }}$ and $18^{\text {th }}$ Centuries, ed. E.B. Vermeer. (Leiden: E. J. Brill, 1990), 222-41.

24 These two fleets left Taiwan in 1679 and 1682. Đai Nam thuc luc [Veritable Record of Dai Nam, ancestral edition] (Hà Nội: Giáo dục, 2002), 125; Trinh Hoai Duc, Gia Định thành thông chi [Unified Gazetteer of Gia Dinh Citadel] (1820, reprinted Hà Nội : Tông hợp Đồng Nai, 2006), vol.3, 77; Wheeler, "Missionary Buddhism”, 217. 
delta in 1698, and the construction of the Gia Định garrison (modern-day Saigon/Ho Chi Minh City), which was the base for Nguyễn expansion of their authority in the Southern Region. ${ }^{25}$ In exchange the Zheng network was officially recognized and rewarded for services to the Nguyễn. They received privileges very similar to those granted by the Nguyễn to the Fujianese diaspora merchants, who also had long been economic allies. These rights included legal recognition as being distinguished communities and settlements where they legally held land rights. Both these were extremely rare grants under the Nguyễn. With the granting of these privileges those of the Zheng coalition then resident in the Mekong Delta completed their transformation from raiders to dominant regional merchants in the Mekong River downstream. ${ }^{26}$ For several decades this ongoing partnership profited the Nguyễn as well as the coastal pirates, some of whom settled into legitimate careers and others who stayed just this side of the law.

25 Yumio Sakurai, 'Eighteenth-Century Chinese Pioneers on the Water Frontier of Indochina', in Water Frontier: Commerce and the Chinese in the Lower Mekong Region, 1750-1880, Li Tana and Nola Cooke eds.. (Lanham, MD: Rowman \& Littlefield, 2004),. 40. 


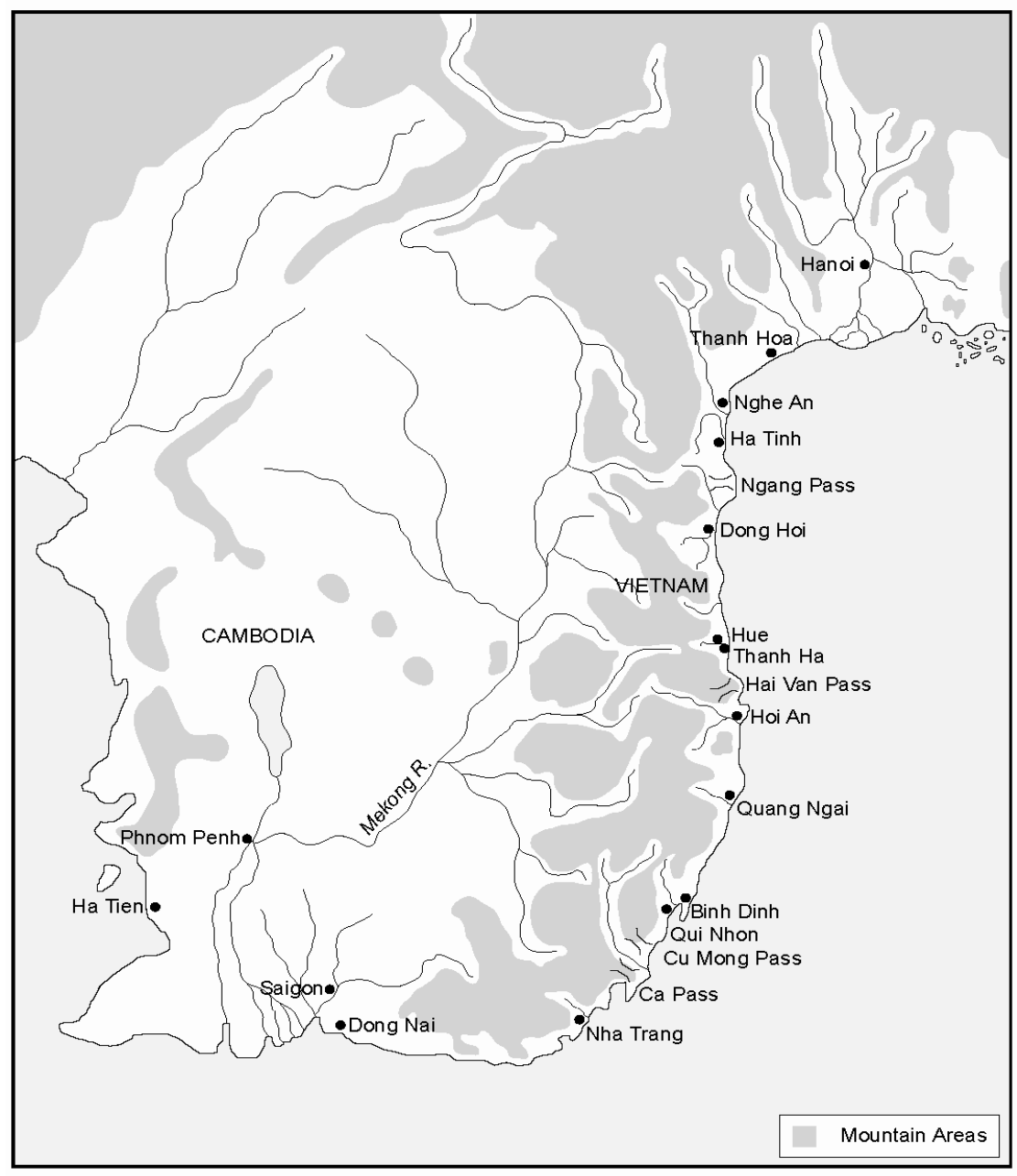

Map. 1: Major coastal ports and cities of the Vietnamese littoral, circa 1700. (Charles Wheeler, "Missionary Buddhism in a PostAncient World: Monks, Merchants, and Colonial Expansion in Seventeenth-Century Cochinchina (Vietnam)" in Secondary Cities and Ubran Networking in the Indian Ocean Realm, c. 1400-1800. Edited by Kenneth R. Hall. (Lexington, 2008). Used by permission of the editor.

With their extension of various privileges (i.e. salvaging, self-government, etc.) to the Zheng-clan confederacy, local piratical groups, and Cham and Japanese raiders who harassed shipping not friendly to their interests, the Nguyễn approach to this area of economic protectionism was conducted in a manner that was an extension of earlier Cham patterns of reciprocal relationship and gift-giving between the lord and local strongmen, and so on down through the various socio-economical groups, so that in general the coastal littoral seagoing populations and their upstream partners publically 
acknowledged their loyalties to the central region-based "giftgiver" Nguyễn Lords. Over the long term these Nguyễnnetworked maritime alliances sustained the development of the realm's upstream and downstream regional trading networks, though the early Western traders who conducted business on the Vietnam coastline were not sympathetic to these long-term local benefits in which they could not participate and which they could not influence, control, or overcome until the nineteenth century. ${ }^{27}$

IV. Chan (Zen) Buddhist Temple Networks as Agents of Centralization

When first establishing themselves in the central region the Nguyễn built upon the existing regional presence and prominence of diasporic Chinese merchants. Most of these were Fujianese from southeast China, who had settled in the central coastline's ports consequent to late fifteenth-century Ming China's imposition of restrictions on China-based commercial activities in the Southern Seas. From Hội An and other coastal secondary ports the Fujian diaspora networked with various upstream resident populations, thereby acquiring the variety of items they would ultimately sell in China, Japan, or other regional marketplaces in the eastern Asian maritime world. Political and military events taking place in early seventeenth-century China made these resident Chinese diaspora merchants increasingly uncertain about their ability to return to their ancestral homelands, and in that prolonged uncertainty responded by financing Chinese resistance against Manchu expansionism in northern China. These defensive efforts ultimately failed, and in 1683 the Manchu overthrew the

27 For various first-hand accounts of the opportunities found by early European merchants in Nguyễn ports of trades including Hội An, see Southern Vietnam Under the Nguyễn:

Documents on the Economic History of Cochinchina (Đàng Trong), 1602-1777. Edited by Li Tana and Anthony Reid. (Singapore: ISEAS, 1993). For a case study of what happened when Europeans challenged Nguyễn exercise of local agency over regional trade see Marc Jasaon Gilbert, "The Collapse of the English Trade Entrepots at Pulo Condore and Bangarmasin and the Legacy of Early British East India Company Urban Network-Building in Southeast Asia", in The Growth of Non-Western Cities: Primary and Secondary Urban Networking, c.9001900. Edited by Kenneth R. Hall. (Lanham, MD: Lexington: 2011), 205-39. 
Ming establishing their own Qing dynasty. Numbers of rebels who had fought against the Qing were in turn exiled and added to the growing number of Chinese diaspora resident in Cochinchina, who faced severe punishments should they return to China.

Needing to sustain themselves and build their resources against the day of their eventual return to and in support their families still in Fujian, these Chinese maritime "refugee" diaspora built their maritime trade-based presence and became economically integrated into the southern coastal region, taking care to never allow economic integration to lead to cultural integration with other resident and sojourning maritime diasporic or semi-permanent trading communities. These included the Eastern Indian Ocean Muslim and Hindu diasporas who passed through Cochinchina's coastal ports, and the Cham and Đai Việt Vietnamese diaspora who in the case of the former were the original residents, and in the case of the latter were increasingly moving into the region in order to avoid both the increasingly restrictive taxation of the Trinh court-based bureaucracy and the hardships of periodic famine and warfare in the north. The Chinese diaspora merchants who had settled in and around Hội An or in its neighbouring coastal ports in the central and southern Vietnam littoral remained physically and socially separate from other diaspora communities, fearing that their extensive continuing interactions with other resident diaspora communities might lead to a dilution the Chinese diaspora's collective strength, identification, and retention of Chinese culture. In that time they considered themselves "merchants without empire." ${ }^{28}$ To reinforce their networked regional trade prosperity, which was in their minds based in no small way to their continuing commitment to their Chinese culture, from the late seventeenth century through the eighteenth, they drew from their substantial profits and invited Chan (Zen) Buddhist monks from Fujian monasteries to establish themselves in and around the coastal

28 Wang Gungwu, 'Merchants without Empire: The Hokkien Sojourning Communities', in James Tracy ed., The Rise of Merchant Empires: Long-Distance Trade in the Early Modern World, 350-1750. (New York: Cambridge University Press, 1990), 79-101. 
communities the Chinese merchants had formed in Cochinchian. They pledged their ongoing patronage as the benefactors in and of the establishment of monastic communities and shrines. Their religious and spiritual presence was meant to provide 'cultural conformity and religious integrity' that would allow the merchants to continue to enjoy both economic prosperity and ethnic purity. ${ }^{29}$

In response to the merchants' invitations, elder Chan monks based in south China monasteries sent waves of their younger clergy to act as "missionaries of the faith". The wealthy locally-resident and ethnically Fujian merchants centered in and around Hội An underwrote the construction of local and regional Chan temples and monasteries. These new hierarchically linked religious institutions served over time as the entry points for the introduction of Chan Buddhism into the central and southern regions of Vietnam, moving from the coastal littoral region to the upstream hinterlands. They achieved this by both treating local deities and religious practices with respect while demonstrating their openness for spiritual dialogue. Similar approaches were used by the Chan acting as missionary monks who regularly sailed the triangular maritime trade route connecting Vietnam coastline ports with those of Japan, Taiwan, and south China. ${ }^{30}$ Significantly, this Vietnam-centered view of the seventeenth-century extension of Chan Buddhism in the South China Sea region refutes previous scholars who had asserted that Mahayana Buddhism at that time was regionally "static," as this would have favoured wider contemporary Southeast Asian regional response and conversions to Sri Lanka-based Theravada Buddhism due to a

29 Charles Wheeler, 'Missionary Buddhism in a Post-Ancient World: Monks, Merchants, and Colonial Expansion in Seventeenth-Century Cochinchina (Vietnam)', in Kenneth R. Hall ed., Secondary Cities and Urban Networking in the Indian Ocean Realm, c. 1400-1800, New York: Lexington, 2008, 208.

30 See Louis Jacques Bergere IV, "The Overseas Chinese Community in SeventeenthCentury Nagasaki," Ph.D. dissertation (Cambridge, MA: Harvard University, 2004), 103-26, Wang, 'Merchants', p. 410, and Wu, 'Orthodoxy', pp. 269-280, as well as Wheeler, "Missionary Buddhism”, 208-10. 
mix of missionary endeavours and dynastic transitions in neighbouring Cambodia, Thailand, and Myanmar/Burma. ${ }^{31}$

The Vietnam Cham Buddhist temples of the post-1400 era centered on the worship of well-known Mahayana Buddhist bodhisattvas, especially those of particular importance to the merchant diasporas. These included Guandi (god of war), Guanyin (Goddess of Mercy/Compassion), who had been the object of centuries of devoted regional worship, and Mazu (Empress of Heaven). Though Mazu had been worshipped locally for some time, in a seventeenth-century inscription her shrine was described as still being in an insignificant hut made of "waddle [sic] and thatch" outside a temple located along the river street in the Chinese diaspora residential section of Hội An. ${ }^{32}$ Chan Buddhist monks are said literally to have laid the foundation for Mazu's elevation to greater prominence inside a new local temple by first erecting altars to her outside the old shrine, and then in the seventeenth century building her a more elaborate and permanent temple of her own. ${ }^{33}$ These "missionary" monks similarly emphasized the Chinese Di-Đà (Maitreya), the Laughing Buddha, who held a special place among the diasporic Chinese communities due to his association with prosperity, as well as by resident and competing Vietnamese and Cham communities in Hội An and in other nearby regional ports-of-trade.

\footnotetext{
31 The Nguyễn were adherents of Mahayana Buddhism that put them at odds with the Confucian-centered court of the Lê and Trịnh in Đai Việt. See John K. Whitmore, "Secondary Capitals of Đai Việt: Shifting Elite Power Bases" in Secondary Cities and Urban Networking in the Indian Ocean Realm, c. 1400-1800 edited by Kenneth R. Hall (Lexington: New York, 2008), 155-75; and Kenneth R. Hall, "Coastal Cities in an Age of Transition: UpstreamDownstream Networking and Societal Development in Fifteenth-and Sixteenth-Century Maritime Southeast Asia" in Secondary Cities, 177-204.
}

32 Ch'en Ching-ho, ed, Shilian Da Shan, Haiwai jishi (Overseas journal), 1699, (Taibei: Guangwen shuju, 1969), Notes on Hội An, 17, as cited in Wheeler, n. 25. See also Hugh R. Clark, "Secondary ports and their Cults: Religious Innovation in the Port System of Greater Quanzhou (Southern China) in the Tenth-Twelfth Centuries" in Secondary Cities, 55-77; and Hugh. R. Clark, Community, Trade, and Networks: Southern Fujian Province from the Third to the Thireenth Century (Cambridge Studies in Chinese History, Literature and Institutions), (Cambridge: Cambridge University Press, 2002).

33 After 1684 the Qing began to sponsor altars and dedicated temples to her in an attempt to win control over the Chinese maritime-based communities. 
The monks reciprocated the favourable local mercantile support they had received and subsequently took actions that tangibly benefitted their merchant patrons and in effect the wider community. This also allowed the benefits of the Buddhist presence to be appreciated by upstream and down residents with the potential for resulting conversion through familiarity. One example of this kind of action that benefitted the Nguyễn, the merchants, and the population involved in trade, involves Abbot Dashan, who during his 1695-1696 visit to Vietnam requested that local monastic communities assist in the [re]building of the important trade road from Hội An to the Nguyễn court at Phú Xuân (Huế). Dashan's actions, which were sensitive to the opportunity to reinforce Nguyễn dynastic support for Chan Buddhist initiatives, are representative of a "missionary religion" able to establish and support branch temples by utilization of internal overland and upstream economic networks of the downstream diaporic merchant colonies to form monastic communities within the host societies that welcomed them, as well as overt political networking with the Nguyễn.

By such actions of reaching out to meet local needs beyond those exclusively of the Chinese diaspora resident community, the Chan monks demonstrated a deliberate and conscious effort to localize Buddhism and regional religious traditions and economic and political needs, in the hopes of attracting more of the regional multicultural populations to the Buddhist faith, as well as to win support from the Nguyễn. Regional Chan Buddhism worship increasingly incorporated minor local deities previously identified with the existing Cham population, thereby making an effort to show they were open to and respectful of local traditions and thus opening the door to the local populations' interest in learning more about Buddhism, with a possible eye towards conversion. The monks' steady success in their spiritual outreach and in the gathering of an inclusive networked regional Buddhist religious community asssisted the diasporic Chinese and localism in satifying the group's communal spiritual and physical needs, and moved well beyond that singular community by having both widespread regional political and economic importance. 
As intended by their initial invitation to the Fujian-based monks, the resident Chinese merchant diaspora found various benefits from the presence of Buddhist temples and monasteries in their regional communities. Locally, "resident" Chinese merchants acquired spiritual merit and local legitimacy via their monetary gifts and/or gifts-in-kind to Chan monastic institutions, and by their association with the faith when the wider community gathered within a Buddhist temple's grounds for services or to conduct meetings. Merchant businesses, guild meeting halls, and markets were strategically adjacent to, or immediately across from, a Chan temple complexes, as seen in Hội An, as these market-based institutions garnered spiritual aura not only from the donations they made, but also from the physical proximity of their guild halls and meetings houses to the temples. Merchants' business gatherings regularly took place within or on the edges of the temple precinct in such spaces as the adjacent temple complex, and marketplaces became the centerpieces of the expanding multi-ethnic and multicultural communities such as Hội An, and neighboring port communities. Over time merchant meetings moved from the periphery of the spiritual complex into the great halls of centrally-located urban-based temples. This was a significant and regular enough occurrence by the late seventeenth century for Abbot Dashan, mentioned above, to make special note of this spatial unity with no displeasure at the coincidence. ${ }^{34}$

While the merchants' patronage was genuinely spiritual in content, it could also make a very pronounced political statement. They used their "gift-giving" subsidization of temple constructions and ritual activities as integral aspects of their wider effort to separate themselves from the increasing presence of resident Chinese Qing dynasty supporters. For example, in the second half of the seventeenth century in Hội An there was a conspicuous frenzy of temple and monastery (re)construction financed by a group of Ming-loyalist Chinese

34 In 1699 Shilian Dashan wrote that the Fujian merchants' guild met in the recently reconstructed Guandi temple and commented that merchants prayed regularly in the temple

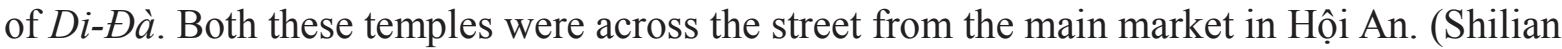
Da Shan, Haiwai jishi (Overseas journal), 1699, ed. Ch'en Ching-ho. (Taibei: Guangwen shuju, 1969), 83, 107. 
merchants and city fathers. The prominent Long An monastery was erected after 1653 on the site of an older Guandidedicated temple where a south China-linked maritime divinity was regularly worshipped by Chinese sojourners. This incorporation of this maritime community divine into the local Buddhist complex symbolized the submission of this "local" divinity to the Buddha, and made a significant statement of emerging religious centrality among the region's populations. Similarly, Hội An's Quang Yen monastery was constructed prior to 1680 , and circa 1688 another monastery dedicated to Di-Đà was built next to the newly constructed Guandi hall, both immediately across from the central market. Similarly, the Chuc Thanh monastery was constructed in 1694-95, the Kim Son monastery in 1696-97, and the Phuoc Lam monastery in 1698. ${ }^{35}$ Hội An's Chinese maritime merchant community was not unusual in its commitment as patrons of Chan Buddhism or in using religious foundations as ways to demonstrate their "right" attitude in religion and in business, and thus, it was thought to imply, in political matters as well. Similar endeavors were undertaken by their Chinese diaspora counterparts resident in other major contemporary Vietnam coastline port communities, including Thanh Hà, Quảng Ngãi, Qui Nhơn, Nha Trang, Đồng Nai, and Hà Tiên, as each had religious and commerical linkages with their respective upstreams. ${ }^{36}$ (See Map 1)

Major seventeenth-century merchant patrons, a mix of Chinese diaspora and prosperous Vietnamese, thus had their permanent residencies in the primary urban centers of the central and southern littoral coast, especially Hội An, rather than in secondary upstream centers of trade. (See Map 1) The principal Chinese merchant patrons emphasized that the leadership of the new and politically important temples had to be initially offered to eminent Chinese Buddhist monks, to add prominence and legitimacy to the Buddhist institutions and to their sponsors. Subsidizing the arrival of Chinese Buddhist

35 Wheeler, "Misionary Buddhism," 211.

36 For more on the details of financing, construction, and hiring of workers, see Wheeler, "Missionary Buddhism," 212 and n. 34. 
abbots of Dashan's stature from a prestigious Fujian-based religious community offered validation to the Chinese diaspora merchant community's continuing networked connection to their homeland, and allowed the recently instituted monasteries and their initial patrons (Chinese merchant diaspora and subsequently the Nguyễn) to bask in the reflection of the dharma genealogy and discipleship that distinguished the central Vietnam monks from those of China and northern Vietnamese lands. ${ }^{37}$ Over time, monks from the central Vietnamese foundations began to head Vietnamese monasteries and established new Buddhist institutions the importance of the Chinese merchant diaspora as community members and as the original if no longer benefactors (thanks to the Nguyễn's taking on of that role over the course of the seventeenth century). Equally the Nguyễn rulers benefitted, as the expansive networked missionary monks and diaspora merchants were laying the institutional infrastructures necessary for an effective linkage between the Nguyễn-held coastline's ports of trades and related marketplaces and residents and their upstream populations who provided the goods they offered for sale, and whose public acceptance of their rule gained them political legitimacy.

The resident Chinese merchant diaspora's acceptance and embracing of the Chan Buddhist monks' syncretic inclusion of non-Buddhist elements from various local religious traditions helped to integrate the Chinese diaspora merchant communities and local residents without tainting the cultural and spiritual purity they wished to maintain. For the community the benefits of such a syncretic approach included the employment of locals to build and sustain the warehouses and buildings necessary to store merchant commodities, skilled workmen to repair and rebuild temples and monasteries, and locals who supplied locally produced raw materials needed for these construction projects. The mix of local and wider marketnetwork exchanges supplied precious woods, gems, and

37 For more on the Nguyễn and their actions to become dharma disciples within the Chan Buddhist tradition, see Ilicia J. Sprey, "Gunpowder, Pirates, Monks, and Books: Maritime Trade on the Vietnam Coastline, c.14-1800"in Vanguards of Globalization: Port-Cities from the Classical to the Modern edited by Rila Mukherjee. (Primus: Delhi, 2014), 300-301. 
stones, as well as skilled craftsmen that made temple construction and decorative community projects possible.

While the Nguyễn needed the merchants as a source of various economic resources, the Buddhist monks also served as a model for their own actions, as the Nguyễn were also an alien northern Vietnam civilization, for how to successfully integrate themselves into the regional social and cultural fabric. Although ultimately of a foreign heritage not unlike the merchants and the monks, Nguyễn monarchs became moral and spiritually trusted authorities by ultimately being respectful of local customs, traditions, and institutions. Among these were the existing merchant and monastic networks, which the Nguyễn monarchs accepted rather than challenging. For better or worse, to bring stability over regionally diverse populations that shared little in common culturally, the Nguyễn promoted themselves as leaders and patrons of the two areas that the population increasingly shared: a desire for economic prosperity that positively affected both upstream and downstream populations directly and indirectly involved in the ports-of-trade commerical activities, and Chan Buddhism that had effectively developed an expanding place for itself in Cochinchina. The Nguyễn set port and market policies that made them both sponsor and guardian of the region's economic growth and development, which ultimately depended on Chinese diaspora-dominated upstream downstream market networks. The Nguyễn also adopted publicly the spiritual wisdom and authority of Buddhist patrons as they took on the mantle of dharma discipleship, positioning themselves squarely in the reflected glow of Buddhist spiritual legitimacy as both cakravartin (universal monarch) and Minh Vurong ("enlightened king"). By such actions they co-opted a share of the monks' moral authority with the central intent of supporting their political legitimacy and dynastic ambitions. Over the course of the seventeenth and early eighteenth centuries the Nguyễn's increasingly conspicuous public relationships with their region's multi-ethnic merchant communities and Buddhist monks and related institutions proved their varied initiatives - economic, spiritual, and inclusion of various and diverse cultural and ehtnic groups - worthwhile, as their intertwined efforts at first 
stabilized and then promoted the newly-established rulers of Trung Bộ (the central coastal region) and Miền Trung Việt ("central Vietnam") both in the eyes of those living in these regions, and among the leadership of foreign courts, particularly that of Qing China.

\section{Initial European Encounters and their Consequence}

Đà Nẵng had been the primary port for the central region, in the fifteenth and sixteenth centuries prior to the advancement of Hội An by the Nguyễn. Đà Nẵng in fact had a superior harbour in many ways and was deep enough for Western merchants ships to make port in. The riverine port of Hội An was near the sea, but not directly on the coast and was therefore more easily defended than other coastal ports, although in time it and its associated river suffered from silting and would periodically have to be dredged. Hội An also had the advantage of being the one port where the Nguyễn allowed foreigners to establish their own warehouses and factories. Hội An was widely known as a port where open commercial exchanges took place without the Nguyễn intruding in the minutiae of trade and so Hội An became the favored central port once the Europeans arrived to trade in the region. ${ }^{38}$ The Nguyễn Lords, following the policies of their patriarch deliberately chose to keep the region's military administrative centre in Huế, just far enough removed from the commercial centre of Đà Năng and even further from Hội An, as each had their own distinctive role to play in the economic development of the region. This decision removed the sense of any political pressure on foreign merchants, as these two most prominent Cochinchina ports operated on the rules of a marketplace rather than those of a government administrative center. Cochinchina, as envisioned by Nguyễn Hoàng, came into being at the height of the commercial maritime trade and economic prosperity ground in the activites of the regional ports-of-trade at the end of the sixteenth and early seventeenth centuries. $^{39}$ 
Hội An's promotion as the region's central port was the action of Nguyễn Hoàng when he was its provincial governor prior to becoming the outright ruler of Cochinchina. ${ }^{40}$ Slightly upstream on the northern bank of the Thu Bồn (Hội An) River, it developed into one of the best situated and important regional ports-of-trade as it lay approximately half-way between Indonesia, at the southern end of the mainstream Indian Ocean maritime trade route between the Straits of Melaka and China and Japan at the northern terminus. ${ }^{41}$ According to details written on the c.1678-80 Chaya Shinrokuro or 'Sea Map' it took approximately 4,320 miles and 40 days to sail from Nagasaki to Jiaozhi (Đà Nãng) and so it would have only taken another day or so for ship pilots to navigate south to Hội An. ${ }^{42}$ According to Chen, an eighteenth-century trader from China's Canton province, "[Hội An was] only six days and nights from Guangzhou via Thuận Hóa and Quảng Nam by sea."43 Thus, Hội An and Đà Nẵng were in strategic geographic positions to take economic advantage of favourable contemporary Chinese and Japanese maritime policies, and any other major alteration in regional trade relationships that required trading through a neutral or third-party port, as China-Japan trade did in this

39 Anthony Reid, Southeast Asia in the Age of Commerce, 1450-1680: The Lands below the Winds. Vol. 1: New Haven: Yale University Press, 1988; Expansion and Crisis. Vol. 2: New Haven: Yale University Press, 1993.

40 The name of Faifo came into usage after 1553 and before 1575. Duong Van An's $O$ Chau Can Luc (Recent notes on O Chau) (1553) mentions villages, but not Hội An. In 1575 the Portuguese merchant Antonio de Faris, wrote of Hội An. (Phan Huy Le, 'Hoi An (Faifo)', in Ancient Town of Hộ An, 17-20.) During the majority of the time covered by the present study, Hội An technically encompassed 6 villages: Hội An, Minh Huong (where Mingloyalist diaspora lived), Co Trai, Dong An, Diem Ho, and Hoa Pho. Nguyễn Dinh Dau, 'The Birth and the Historical Evolution of Hoi An', in Ancient Town Hoi An, 121

41 Charles Wheeler, "A Maritime Logic to Vietnamese History? Littoral Society in Hoi An's Trading World c.1550-1830", Paper presented at Seascapes, Littoral Cultures, and TransOceanic Exchanges_, Library of Congress, Washington D.C., February 12-15, 2003. http://www.historycooperative.org/proceedings/seascapes/wheeler.html

42 Ogura Sadao, 'About Two Japanese Scrolls: "Sea Map-trade with the State of Jiaozhi" and 'Avalokitesvara", in Ancient Town of Hộ An, pp. 128-9, and Chojara Daigoro, "About the Constructions Described in Chaya Shinrokuro's "Sea Map": Trade with the State of Jiaozhi", in Ancient Town of Hội An, 30.

43 Quoted in Lê Quý Đôn, Phủ biên tạp lục, (Ha Noi: khoa học xã hội, 1977), vol. 4, 34b. 
period. Hội An under the Nguyễn profited from the increasing trade brought to its wharfs by Asian and European sojourners over the course of the seventeenth century in particular. ${ }^{44}$ Hội An's location near the middle of the major southern and western (Philippines to Melaka) ${ }^{45}$ trade routes was critical, but there were other geographic realities that contributed to its success. As discussed above, ships sailing along the southeastern and central Vietnamese coastline had a narrow path through which they could safely navigate due to the countless sandbars and reefs of the Spratly Islands and the Paracels. This 'safe' route was close enough to the shoreline to encourage stopovers for stocking up on supplies and the trading of goods to earn a little more silver, or to rest in the hospitable and well-equipped ports of Hội An and Đà Nẵng. In storms or if sailing late in the monsoon season both offered protection, although Hội An was considered safer in storms and monsoon season due to its being located upstream. The monsoon season was primarily from August to November, and most trading along the littoral's coast was done between April and 20 July at the latest. There was thus a seasonal window of opportunity when shipping laid over at Hội An. Local merchants and the Nguyễn exploited this window by establishing an annual four-month fair to maximize the possibility of selling and buying goods desired elsewhere along the Indian Ocean regional maritime route, and this benefitted the Western merchants and ship captains as much as the Nguyễn.

The first Vietnamese contact with Europeans came in 1516, when Portuguese, blown off-course in their southwest monsoon season travels from Melaka to south China, landed at the site of modern-day Đà Năng. ${ }^{46}$ Having explored the regional trade potentials and available ports, they established a trade base in 1540, following a visit by the Portuguese envoy Antonio

44 George Bryan Souza, The Survival of Empire: Portuguese Trade and Society in China and the South China Sea, 1630-1754. (Cambridge: Cambridge University Press, 1986), 16-17. 
da Faria (d. 1548), who decided that Hội An (which he called Faifo) was the most prominent and strategically located contemporary port of trade on the central Vietnam coastline. The Portuguese were most interested in securing a layover for their China trade; navigation from Hội An to south China's ports was more direct than that from the upper Gulf of Tonkin ports servicing Hanoi. While they initially intended to make Hội An into a Portuguese fortified stronghold similar to Goa and Melaka, they did not succeed. Trade in the regional ports was well established and local agency effectively exercised by Nguyễn Hoàng who, as militiary governor, would allow the Portuguese to trade, but not to dominate local trade. Unable to make any signficant inroad in Hội An, the Portuguese focused on acquiring such goods as yellow silk (second in quality to that of China), fragrant woods including eaglewood and calembac, and benzoin and copper, and developing more trading relations and entrepots with northern Vietnam's rulers and in China. ${ }^{47}$ From the perspective of the Nguyễn, whether as military commander or later as Lord of Trung Bộ, the Portuguese were a useful source of gunpowder weapons and also of tradederived revenues consequent to their negotiated linkages with Japan and China marketplaces, but the Nguyễn were not going to be bullied by them.

Hội An's importance in international trade spiked during the late sixteenth century, when China's rulers imposed hai jin ("ocean forbidden") law embargos on Japanese ships and limited Chinese commercial exports to Japan. This followed the Ming dynasty's 1567 relaxation of restrictions on Chinese overseas trade with Southeast Asia that had been in place for over a century. Consequently, Hội An became the vital intermediary port-of-trade in the Japan-China marketplace, receiving Chinese products to which were added locally produced silks and porcelains and goods brought in from Thai and Khmer markets that were highly in demand in the evolving Japan marketplace. Most of Hội An's Japan shipments were initially transported by Japanese ships. It was during this era

47 C.R. Boxer, ed. and translator, Seventeenth Century Macau (Hong Kong: Heinemann Educational Books, 1984), 37. 
that numbers of Japanese took residence in Hội An, where to this day there remains a "Japanese bridge" and "Japanese street" as cultural and historical markers of this group's importance in the economic life of the city and its port. Both the Chinese and Japanese governments accepted Hội An as a suitable intermediary port-of-trade, because it was strategically located near both to provide linkage between the northern and southern China Seas, and was politically independent enough to be free of Chinese, Japanese, or European military or diplomatic pressure.

The Dutch entered into the littoral's ports-of-trade following on the heels of the Portuguese in a far more militant fashion but with an equal lack of success. ${ }^{48}$ In Cochinchina the Nguyễn were able to effectively resist Dutch strong-arm tactics that had been applied with great effect in Melaka. This was due to the Nguyễn's alliances with the Portuguese, who wished to see the Dutch crushed if at all possible by regional forces. The Nguyễn gained access to Portuguese-produced high quality cannon with which they protected their ports and shores from Dutch raids. Unable to conquer or intimidate the Nguyễn and in need of a midway trading post that would supply many of the goods the Japanese and some European and Indian markets were seeking, Dutch ships laden with Japanese silver and goods began to appear more often in Cochinchina's ports. Despite their resentment over how they were treated - not as favored trading partners, but one among equals, the Dutch established a lodge (factory) in Hội An in 1633. As their trade base for their exchanges with Japan, it took on great strategic and financial importance for both the Dutch and the Nguyễn, but for different reasons. Despite the mutual benefits of this trading relationship as found in the over 7000 Vereenigde Oost-Indische Compagnie [Dutch East India Company] documents related to Tongking and Cochinchina in this period, the Dutch expressed significant prejudicial against the Nguyễn, who were too independent for VOC tastes. ${ }^{49}$ 


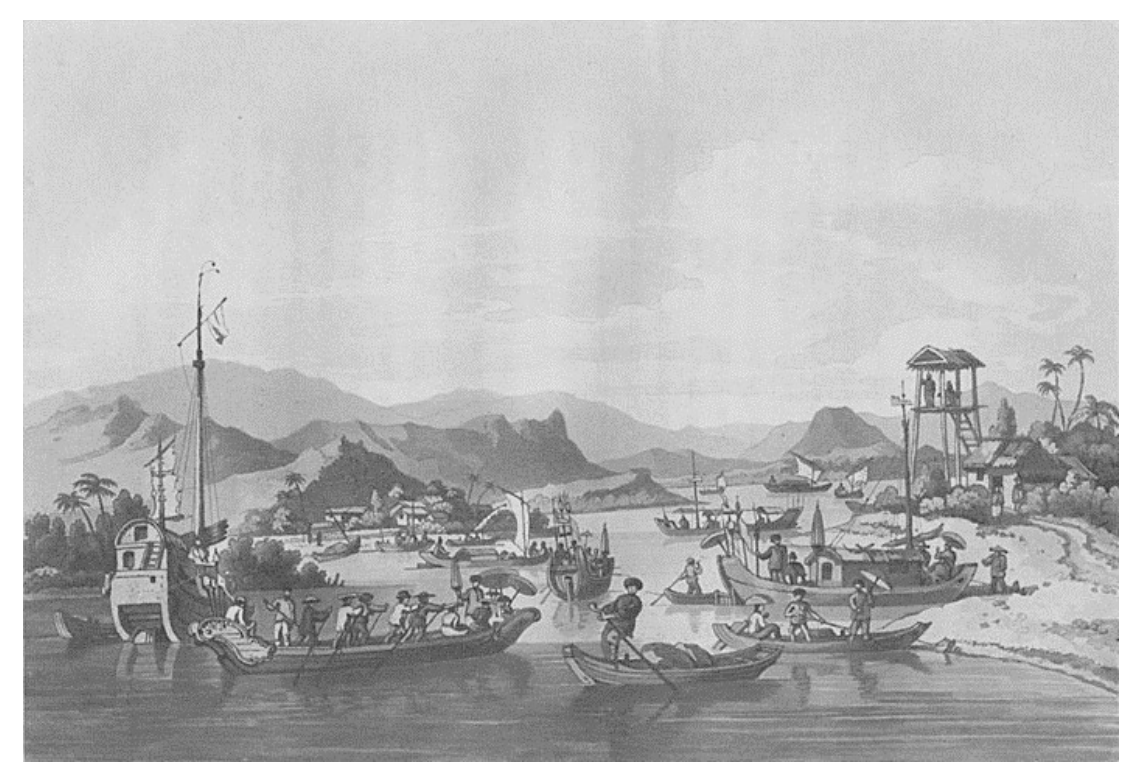

Image 1: A voyage to Cochinchina in the years 1792 and 1793: Faifo (Hội An) by John Barrow, London : printed for T. Cadelland W. Davies in the Strand, 1806. -XVIII, p. 447. This image illustrates the busy nature of Cochinchina's ports as reported by Chinese merchants, Buddhist monks such as Dashan, and the French Jesuit Alexandre de Rhodes in the seventeenth and eighteenth centuries.

The British East India Company was the third European trading power to enter the regional marketplace with their establishment of a factory in Hirado (Japan) in 1613, but failed in several seventeenth-century attempts to follow the Dutch example in setting up a profitable Vietnam trade base. From 1672-1697, the British had a factory in the Tonkin Gulf. They tried first to secure high quality Vietnamese silk for the London marketplace in the Nguyễn controlled ports-of-trade, but when they were unable to dominate or even establish a reasonable foothold in the market, the British East Company's management in 1701 undertook the building of their own factory on Pulo Condore, an island in the South China Sea, just off the southern shore of the Vietnamese littoral. As the factory was nearing completion the Nguyễn hired the Bugi population brought in as labors to attack and destroy the settlement and factory, and there was a nearly complete massacre of the 
English population then resident there. ${ }^{50}$ This ended the English and all European attempts to circumvent Nguyễn control over the ports-of-trade related markets until the Tây Sơn Rebellion (1771-1802) helped to overthrow the Nguyễn Lords and nearly destroy the family.

The French were the last of the major European trading entities to come to the Vietnamese littoral and the South China Sea. Their early efforts were reported by Alexandre de Rhodes, a French Jesuit missionary, assigned there in 1627, who wrote of his experiences in Vietnam, particularly in Đai Việt, although he also travelled to the central coast. In his book Divers voyages et missions (Paris 1653) he shared his awe of the over fifty ports of good size and depth in the central region that could allow fifteen to twenty ships to lie at anchor at the same time and that were so safely held there that they did not need to drop anchor. ${ }^{51}$ In his observations he also wrote very positively about the Vietnamese people and the Vietnam marketplace's potentials for Western profit. The French ultimately established a factory at Phố Hiến in 1680, but closed it within two years as the mid-seventeenth-century peak of the European South China Sea trade had ended. The regional trading economy could not sustain its previous pace and by the 1720s inflation along with the downturn in trade was ruining Cochinchina's economy which was dependent upon Japanese silver and other foreign coins as the backbone of its currency as the Nguyễn did not mint their own coins. European withdrawal and a general regional decline in coastal and regional trade and a subsequent increased demand by the Nguyễn to collect previously neglected taxes from its diverse popoulations to support its military ambitions and growing bureauracy led to economicallyrooted social and political unrest mixing with cultural resentments among the diverse multi-ethnic groups that had previously accepted Nguyễn rule, so long as it economically and socially benefitted them. With the economic prosperity on which the Nguyễn based their administrative and military

50 Gilbert, "The Collapse of the English Trade Entrepots", op. cit.

51 Alexandre de Rhodes, Histoire du royaume de Tunquin (Lyon: Jean Baptiste Devenet, 1651), 56-57. 
strength gone, their spiritual authority was also called into question and they became the object of local violence and regional uprisings that culminated in the Tây Sơn Rebellion (1771-1802) that nearly killed every member of the Nguyễn clan.

VI. Conclusion

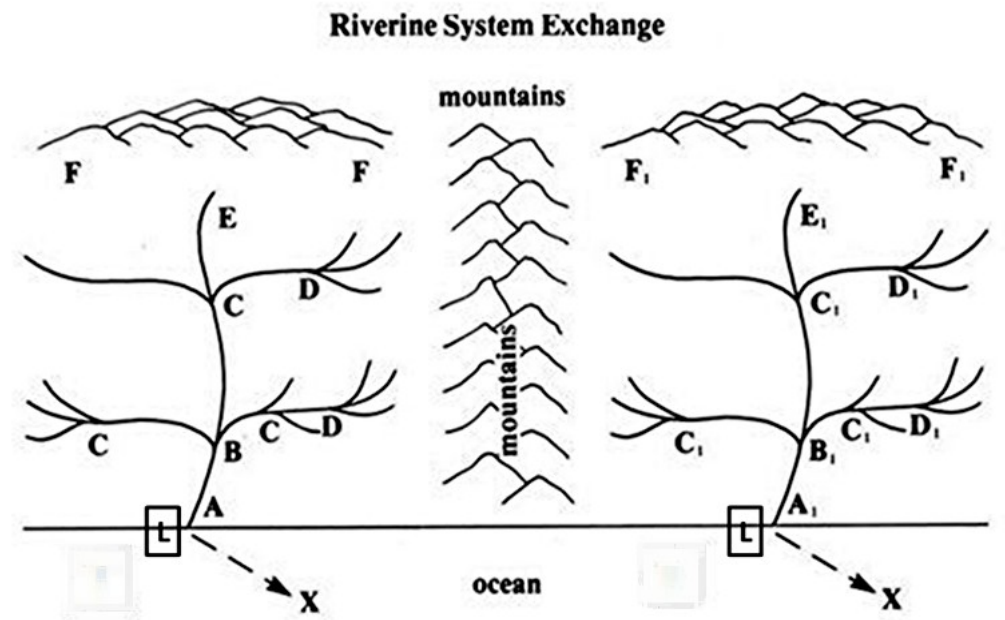

Figure 2: Bennet Bronson, 'Exchange at the Upstream and Downstream Ends: Notes Toward a Functional Model of the Coastal State in Southeast Asia.' in Economic Exchange and Social Interaction in Southeast Asia: Perspectives from Prehistory, History, and Ethnography, ed. K. H. Hutterer. (Michigan Papers on South and Southeast Asia No. 13. Ann Arbor: Center for South and Southeast Asian Studies, University of Michigan., 1977), p. 42.

Thus far the paper has described and provided evidence for how the Nguyễn were able to sustain their independence from Đai Việt from the late sixteenth century through to the later eighteenth century based primarily on the commercially-derived revenue of its coastal ports, particularly Hội An and Đà Năng. These ports-of-trade were in turn dependent for the raw materials and finished goods supplied to its marketplaces by the upstream and hinterland populations and by other approaches including collaboration with Thai and Khmer markets to avoid undue regional competition and underselling. Moving into the more theorethical realm, Figure 2 provides a graphic of decentralized Southeast Asian riverine systems as originally invisioned by Bennet Bronson in the 1970s that is 
applicable to a certain extent to the central and southern Vietnamese coastline under the Nguyễn as detailed in this study. This representaion and understanding of Southeast Asian and East Asian trading network was refined by Charles Wheeler in his 2001 dissertation on the central coastal region of the Vietnamese littoral. ${ }^{52}$ (See Fig. 3) In the era covered by the present study the primary ports-of -trade of Hội An and Đà Năng are represented by $A$ and $A_{1}$ as identified by Bronson as these are at the mouth of riverine systems separated by mountains. Points $B$ and $C$ are secondary and third order centers located at upstream primary and secondary river junctions. $D$ identifies distant upstream centers, the initial concentration points for products originating in more remote parts of the river watershed; $E$ and $F$ are the non-market productions center in the upland that are the source of foodstuffs, forest products, and exotic items as detailed. A central idea to keep in mind, however, and why Wheeler's revised graphic is useful is that whereas Bronson wrote of pressure and force being used to control the lesser upstream partners in this network, in the case of the Nguyễn, being an ethnically, culturally and religious minority, they had no overt pressure to bring to bear that would have been as effective or as stabilizing as the alternate approach they took. That approach was partnership, collaboration, and adapation to groups already regionally present (Fujian diaspora merchant) or at least regionally well-respected (Fujian-based Buddhist monks). The Nguyễn made deliberate efforts to incorporate and integrate themselves into the local cultures, particularly that of the Cham, by honoring local dieties such as Po Nagar, and through the seventeenth century, it also meant setting aside any effort at culturally "civilizing" the diverse populations of Đàng Trong by "Vietnamization," opting instead to adopt a stance of cultural and ethnic toleration and inclusion.

52 William A. Southworth, "River Settlement and Coasta Trade: Towards a Specific Model of Early State Development in Champa," in The Cham of Vietnam: History, Society and Art. Edited by Tran Ky Phuong and Bruce M. Lockhart. (Singapore: NUS, 2011), 102-19. 


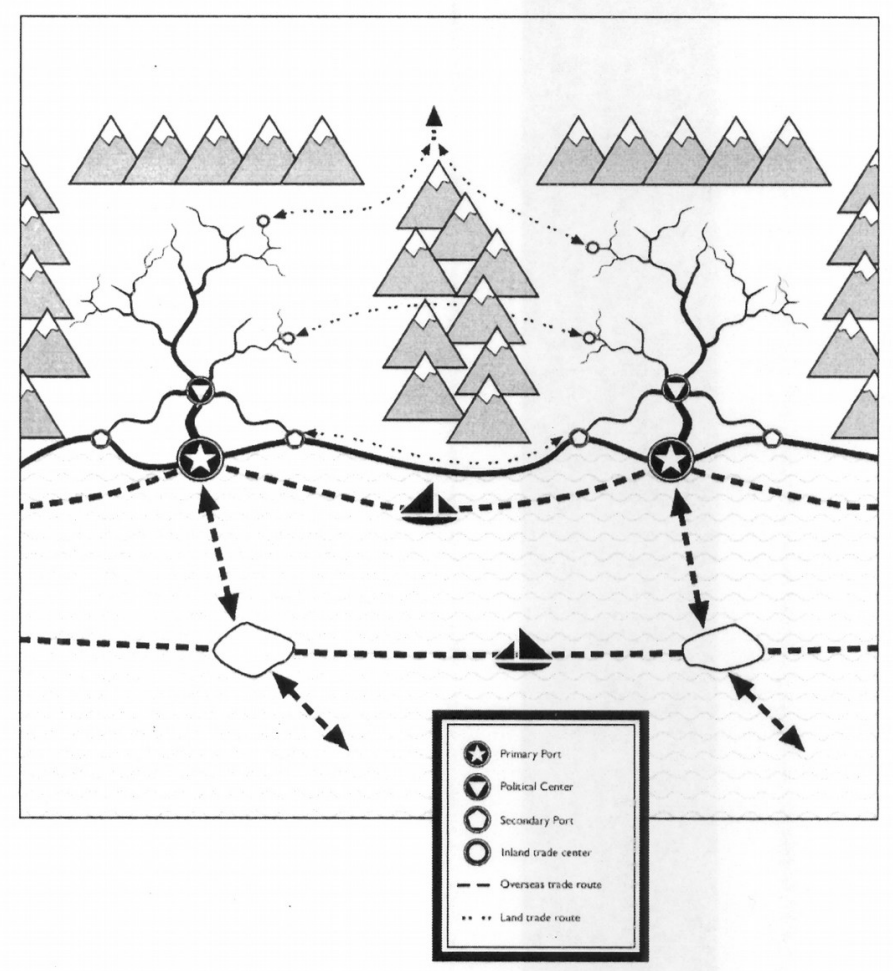

Fig. 3: Charles Wheeler, Maritime subversions and sociopolitical formations in Vietnamese history" in New Perspectives on the History and Historiography of Southeast Asia: Continuing Explorations. Edited by Michael Arthur Aung-Thwin and Kenneth R. Hall. (Routledge, 2011), p. 145. Used with permission of the editor.

Bronson and Wheeler are useful models, and in the case of the former it fits in neatly with and in the case of the latter it builds upon ideas offered earlier by Michael Pearson. In the case of the Bronson diagram $L$ depicts the littoral coastline region as addressed in Pearson's various writings over the last two decades. ${ }^{53}$ The Vietnam coastline as described is consistent with Pearson's depiction of the littoral coastal activity zone, where there were various ethnic residential communities characterized by different degrees of residency. In the case of the Nguyễn controlled central lands in the seventeenth century, the focus was on participation in coastal, regional, and transregional maritime-based trade. This is a break from the traditional understanding by historians of polities in this region

53 While the idea of the littoral is found as a constant theme in most of Michael Pearson's writings, a primary reference point where his argument is neatly laid out for the reader is in The Indian Ocean. (New York: Routledge, 2003). 
being primarily focused on agriculture. As Pearson theorized, Europeans who focused on maritime trade were able to "claim" control of the seas as the majority of Asian and South Asian polities focused on agricultural and land-based revenue streams. $^{54}$ The Asian and South Asian rulers and those engaged in commerical activity in a general sense saw the maritime passageways as the "seas common to all" 55 and did not seek to control them as the Europeans did whether in the Mediterranean Sea, the Carribean or the Indian Ocean.

Whether it was that the Nguyễn, having already broken politically and psychologically with the northern court felt free to take a path away from the binds of Confucian expectations to maintaining formal relationships within society and thinking, and electing to act in new and more open culture and political patterns of the era, or the practical necessity of surviving and thriving as an alien Viet minority ruling cohort among a culturally diverse population upon whom they were dependent for revenue and military manpower, the Nguyễn actively engaged in maritime-based commerical activity in multiple and interwoven ways and exercised meaningful local agency. Over the generations they were able to consistently enforce that authority in a manner that allowed them to control both their port-based markets and the shipping lanes. ${ }^{56}$

The approaches included the revitalization of formerly significant Cham ports such as Đà Năng and the advancement of well-positioned but previously less important ports-of-trade such as Hội An. They deliberately sought collaboration with foreign transient and diaspora merchant communities, and

54 Tonio Andrade, "Asian states and overseas expansion, 1500-1700: An approach to the problems of European exceptionalism" in Asian Expansions: The historical experiences of polity expansion in Asia. Edited by Geoff Wade. (London: Routledge, 2015), 52-68.

55 "God has made the earth and the sea, and has divided the earth among men and made the sea common to all," Sultan of Makassar (Indonesia) to the Dutch ambassador (1659) as cited by Craig Lockard, "The Sea Common to All": Maritime Frontiers, Port Cities, and Chinese Traders in the Southeast Asian Age of Commerce, ca. 1400-1750," Journal of World History, 21:2 (June 2010), 219-47.

56 Li Tana, "An Alternate Vietnam? The Nguyen Kingdom in the Seventeenth and Eighteenth Centuries," in JSEAS, 29, 1, 1998, p. 120 and Keith W. Taylor, "Nguyễn and the Beginning of Vietnam's Southward Expansion," 64. 
attracted foreign merchants and trading vessels by the various practices including non-preferential pricing of goods, of religious toleration, by acting as supporters of foreign religious communities, and lastly by finding allies among foreign maritime-based political rebels (much like themselves) in the form of Ming-supporters and piratical confederacies such as that of the Zheng. The Nguyễn successfully paired practical necessity with economic need. Over the course of the seventeenth century in particular, they were able to effectively introduce and exercise meaningful local agency. This local agency is shown in its ability to negotiate collaborative and mutually beneficial trade agreements with its Thai and Khmer neighbors that brought the goods those regions produced and that were highly prized to Nguyễn-controlled ports for sale as part of the larger regional and transregional trade routes through the South China Sea and neighboring waters. The Nguyễn displayed effective local agency in being able to gain a signficant role in the Vermillion Ship trade with Japan and in its trade relations with China. They attracted transient, semipermanent, and permanent foreign communities of traders to their ports while maintaining a marketplace and non-preferential pricing for any particular group no matter the economic or militant pressure brought to bear. This later policy was particularly resented by the Dutch who attempted to first bully and then use their military might to gain marketplace pricing advantanges. In that confrontation the Nguyễn succeeded in holding their position and authority intact. Similarly, when the English attempted to establish a rival trading center at Pulo Condore, the Nguyễn again exercised their commercialmaritime control by the strategic use of violence in destroying so thoroughly the English factory that any effort to establish such a rival base was not attempted by another European power for more than a century. As such, the Nguyễn Lords period of authority over Đàng Trong particularly in late-sixteenth and seventeenth centuries provides another area in which Pearson's ideas regarding domination of maritime-based trade in this era can be appropriately applied. As demonstrated again and again by Nguyễn Hoàng and his successors who ruled over Cochchina from the late sixteenth through late eighteenth 
century to profit from its maritime-based commerce, a riverine state needed only to seize a rival's river-mouth center, not its hinterland, in order to generally dominate the inclusive networks of its interwined and mutually interdependent riverine and hinterland systems. While there might be a general Southeast Asian and Asian sense in this era that the seas belonged to all, for the Nguyễn they were determined to hold sway over not only the upstream and hinterland resources that supplied their ports-of-trade, but also those shipping lanes that ran along their coastal shores as well as the trade routes to the north, east, and south that they were supplying and to defy any group, whether from the northern kingdom or Europe who attempted to intrude either into waters or markets they clearly saw as theirs. 